Elsevier required licence: $(c)<2018>$. This manuscript version is made available under the CC-BY-NC-ND 4.0 license http://creativecommons.org/licenses/by-nc-nd/4.0/ 


\title{
Problematic effects of antibiotics on anaerobic treatment of swine wastewater
}

\author{
D. L. Cheng ${ }^{\mathrm{a}}$, H. H. Ngo $0^{\mathrm{a}, *}$, W. S. Guo ${ }^{\mathrm{a}, \mathrm{b}}$, S. W. Chang ${ }^{\mathrm{b}}$, D. D. Nguyen ${ }^{\mathrm{b}}$, S. Mathava
} $\mathrm{Kumar}^{\mathrm{c}}$, B. Du ${ }^{\mathrm{d}}, \mathrm{Q}$. Wei ${ }^{\mathrm{e}}$, D. Wei ${ }^{\mathrm{d}}$

${ }^{a}$ Centre for Technology in Water and Wastewater, School of Civil and Environmental Engineering, University of Technology Sydney, Sydney, NWS 2007, Australia

${ }^{b}$ Department of Environmental Energy \& Engineering, Kyonggi University, 442-760, Republic of Korea

${ }^{c}$ Institution of Research and Development, Duy Tan University, Da Nang, Vietnam

${ }^{d}$ School of Resources and Environment, University of Jinan, Jinan 250022, PR China

${ }^{e}$ Key Laboratory of Chemical Sensing \& Analysis in Universities of Shandong, School of Chemistry and Chemical Engineering, University of Jinan, Jinan 250022, PR China

*: Corresponding authors: $1^{\text {st }}$ corresponding author: H. H. Ngo; E-mail address: ngohuuhao121@gmail.com 


\section{Abstract}

36 Swine wastewaters with high levels of organic pollutants and antibiotics have become

37 serious environmental concerns. Anaerobic technology is a feasible option for swine

38 wastewater treatment due to its advantage in low costs and bioenergy production.

39 However, antibiotics in swine wastewater have problematic effects on micro-organisms

40 and the stability and performance of anaerobic processes. Thus, this paper critically

41 reviews impacts of antibiotics on $\mathrm{pH}, \mathrm{COD}$ removal efficiencies, biogas and methane

42 productions as well as the accumulation of volatile fatty acids (VFAs) in the anaerobic

43 processes. Meanwhile, impacts on the structure of bacteria and methanogens in

44 anaerobic processes are also discussed comprehensively. Furthermore, to better

45 understand the effect of antibiotics on anaerobic processes, detailed information about

46 antimicrobial mechanisms of antibiotics and microbial functions in anaerobic processes

47 is summarized in this review. Future research on deeper knowledge of the effect of

48 antibiotics on anaerobic processes are suggested to reduce their adverse environmental

49 impacts.

50 Keywords: Antibiotics, Anaerobic processes, Swine wastewater, Impacts, Micro-

51 organisms

\section{1. Introduction}

53 In the last few decades, swine farming has changed from small family farms to

54 large concentrated animal feeding operations (CAFOs) to increase pig production at

55 lower cost (Moses and Tomaselli, 2017). According to the research conducted by the

56 Worldwatch Institute, CAFOs now account for 55\% of pork production worldwide.

57 However, intensive pig production requires frequent use of antibiotics for disease

58 control and growth promotion. Consequently, large amounts of wastewater with high

59 concentrations of organic pollutants, antibiotics and other toxicants was produced by 
60 CAFOs (Cheng et al., 2018). Anaerobic treatment technology has been widely used to

61 treat swine wastewater (the concentrations of $\mathrm{COD}, \mathrm{NH}_{3}-\mathrm{N}, \mathrm{TN}$ and TP are $3000-$

$6215,000,400-1400,600-2100$ and 100-250 mg/L, respectively) (Cheng et al., 2018). As a

63 cost-effective technology, anaerobic treatment consumes less energy to remove

64 pollutants and generate methane rich biogas (Guo et al., 2015b; Sui et al., 2017).

65 Besides, the smaller amounts of sludge production in anaerobic processes also minimize

66 the risks associated with discharging antibiotics and antibiotic resistance genes in sludge

67 to the environment (Xiong et al., 2017).

68 However, we cannot ignore the possibility that antibiotics in swine wastewater

69 could pose serious problems to micro-organisms in anaerobic processes. They could

70 reduce the microbial activities or change microbial populations, influencing the

71 pollutants removal and biogas production (Ji et al., 2013). Currently, some studies have

72 confirmed that the introduction of antibiotics influences the performance of anaerobic

73 systems (Loftin et al., 2005; Poels et al., 1984). Others conclude that the presence of

74 antibiotics in the anaerobic processes could result in a changed microbial structure by

75 shifting microorganisms to less sensitive ones to specific antibiotics or by developing

76 strains with antibiotic resistant genes (Angenent et al., 2008; Shimada et al., 2008).

77 The most frequently detected classes of antibiotics in swine wastewater are

78 sulfonamides, tetracyclines and macrolides, with the concentration of 324.4, 388.7 and

$7972 \mu \mathrm{g} / \mathrm{L}$, respectively (Cheng et al., 2018; Li et al., 2017; Tong et al., 2009; Wei et al.,

80 2011). These antibiotics have different modes of action on microorganisms, like

81 interfering with the functions of cell membranes, blocking protein synthesis and

82 preventing nucleic acid synthesis (Walsh, 2003). In anaerobic processes, several

83 microbial groups convert complex organic compounds to simple, chemically stabilized

84 ones. The coaction of bacteria and methanogens is critical to high-rate and stable 
anaerobic treatments (Aydin et al., 2015e; Town et al., 2014). The presence of antibiotics during the anaerobic treatment process could disrupt the balance. In this case, the accumulation of metabolic intermediates like VFAs would seriously inhibit the anaerobic treatment efficiency (Ji et al., 2013).

Considering the prevalence of anaerobic technologies for treating swine wastewater and the adverse effect of antibiotics on the environment, researchers started to investigate the performance of anaerobic treatment processes in removing antibiotics and their corresponding resistance genes (Cheng et al., 2018). In order to improve the treatment performance, the inhibition effect of antibiotics on the anaerobic treatment processes has aroused great concern. In this review paper, the impact of antibiotics on the treatment performance of anaerobic systems and the shift of microbial communities will be discussed respectively. It will help greatly to improve the stability and efficiency of the anaerobic treatment of swine wastewater with antibiotics, and reduce the emission of these antibiotics to the environment. Additionally, this review is helpful for understanding: firstly, the microbial relationships in anaerobic processes; and secondly, the impacts of antibiotics on the dynamics of anaerobic microbial communities.

\subsection{Antibiotic classes and antimicrobial mechanisms}

$$
\text { Based on the antimicrobial mechanisms, the classifications of antibiotics are }
$$
summarized in Fig. 1 (Cheng et al., 2018; Kapoor et al., 2017). The classes of sulfonamides, tetracyclines and macrolides are bacteriostatic antibiotics. They limit the growth of microorganisms by interfering with their protein production, DNA replication, or other aspects of cellular metabolism, but do not necessarily kill them. Meanwhile, $\beta$-lactam antibiotics like amoxicillin and penicillin have the ability to kill microorganisms by inhibiting cell wall synthesis or inhibiting enzymes or protein translation (Kohanski et al., 2010). Nonetheless, there is not always a precise distinction 
between bacteriostatic and bactericidal antibiotics. Some high concentrations of bacteriostatic antibiotics also may kill microorganisms (Ocampo et al., 2014). Antibiotics with different modes of action are known to have various effects on micro-organisms in anaerobic treatment processes. In particular, sulfonamides inhibit the synthesis of folic acid required for synthesis of purines and nucleic acid by preventing the addition of para-aminobenzoic acid into the folate molecule through competing for the enzyme dihydropteroate synthetase. Tetracyclines and macrolides inhibit protein synthesis by reversibly binding to receptors on the $30 \mathrm{~S}$ and $50 \mathrm{~S}$ ribosomal subunit of microbes (Tenover, 2006). The ribosomes of archaea and bacteria are relatively dissimilar in terms of size and shape, and consist of between 50 and 70 proteins depending on the species. They incorporate three rRNA molecules: $16 \mathrm{~S}, 23 \mathrm{~S}$ and 5S rRNA. Some archaeal r-proteins are also closer in characteristics to the eukaryote ribosomal proteins (Ramirez et al., 1993). All cells require folic acid, but as it cannot enter bacterial cells, they have to manufacture folic acid themselves.

Sulfamethoxazole (SMX) inhibits a critical enzyme, dihydropteroate synthase, and therefore restricts the growth of the bacteria (Hong et al., 1995). These antibiotics impact only on bacterial ribosomal proteins and bacterial cells and do not affect archaea ribosomal proteins and cells (Aydin et al., 2015c). Conversely, $\beta$-lactams are able to inhibit bacterial cell wall synthesis, and then lead to the death of bacterial cell due to osmotic instability or autolysis (Kohanski et al., 2010).

\subsection{Microbial functions in anaerobic processes}

Under the action of micro-organisms, anaerobic processes are divided into four phases: hydrolysis, acidogenesis, acetogenesis, and methanogenesis, as shown in Fig. 2. Micro-organisms in each phase co-operate with each other to convert organic materials to methane and $\mathrm{CO}_{2}$ in a step-wise reaction (McInerney et al., 2009). Hydrolysis and 
acidogenesis are the initial phases of anaerobic digestion. Hydrolytic bacteria degrade complex polymers like carbohydrates, proteins and fats into sugars, amino acids and long chain fatty acids, respectively. Subsequently, this phase is followed by the action of acidogens, which convert water-soluble chemical substances and end products of hydrolysis to short-chain organic acids (formic, acetic, propionic, butyric, and pentanoic), methanol, ethanol, $\mathrm{CO}_{2}$, and $\mathrm{H}_{2}$ (Ali Shah et al., 2014). Acetate, $\mathrm{H}_{2}, \mathrm{CO}_{2}$, and methyl compounds can be directly used by methanogens, while other intermediates formed via acidogenesis, such as propionate, butyrate, isobutyrate, valerate, isovalerate, and ethanol, have to be further bio-degraded through syntrophic acetogenesis to form acetate, $\mathrm{H}_{2}$, and $\mathrm{CO}_{2}$ before methanogens utilize them to produce methane (Venkiteshwaran et al., 2016). As described in Fig.3 (Ariesyady et al., 2007; González-Fernández \& GarcíaEncina, 2009; Guo et al., 2015a; Lang et al., 2015; Sánchez-Andrea et al., 2014; Stone et al., 2009; Suhadolnik et al., 2017; van de Werken et al., 2008; Vanwonterghem et al., 2016; Wang et al., 2017a; Wang et al., 2016), bacteria species in Firmicutes, Bacteroidetes, Thermotogae, Proteobacteria, Actinobacteria, Chloroflexi and Spirochaetes phyla are the function bacteria in anaerobic processes (Ali Shah et al., 2014; Guo et al., 2015a; Venkiteshwaran et al., 2016; Yang et al., 2014). In particular, within the previously mentioned phyla, the genera of Caldicellulosiruptor, Butyrivibrio, Acetivibrio, Anaerococcus, Clostridium, Spirochaeta, Halocella and Bacteroides have the ability to degrade cellulose-, hemicellulose- and pectin-containing biomass to acetate, $\mathrm{CO}_{2}$, and hydrogen or ethanol (Blumer-Schuette et al., 2008; van de Werken et al., 2008). The genera of Bacteroides, Escherichia, Thermotoga and Halothermothrix can convert particulate materials like carbohydrates, protein and animal fats into dissolved materials. The microbes in Proteobacteria phylum also play important roles in 
anaerobic digestion process, because most of them are well known propionate, butyrate, and acetate-utilizing microbial communities (Ariesyady et al., 2007).

As is already known, the accumulation of VFAs can destroy methanogens activity and result in the failure of anaerobic processes. Thus, converting intermediary metabolites into acetate and other substrates used by methanogens is important to retain the balance of anaerobic processes. Some members belonging to the Firmicutes, Proteobacteria and Chloroflexi phyla, like Syntrophomonas, Streptococcus, Pelotomaculum, Syntrophobacter, and Smithella are syntrophic bacteria. They can degrade various VFAs into acetates and hydrogen used by methanogenic bacteria (González-Fernández \& García-Encina, 2009; Schink, 1997; Stone et al., 2009; Wang et al., 2017a). However, the release of hydrogen may be toxic to the microbial community at this stage, since the build-up of hydrogen partial pressure to more than $10^{-4} \mathrm{~atm}$ will inhibit the destruction of propionate and butyrate intermediates (Venkiteshwaran et al., 2016). Therefore, a symbiosis between acetogenic bacteria and autotrophic methane bacteria which consume hydrogen to produce methane is necessary (Ali Shah et al., 2014).

The last phase of anaerobic processes is occupied by methanogenic archaea, which degrade the products of previous phases, such as acetic acid, $\mathrm{H}_{2}, \mathrm{CO}_{2}$, formate, methanol, methylamine, or dimethyl sulphide to methane (Ali Shah et al., 2014). During this phase, species mainly belong to four phylogenetic orders of methanogens, namely, Methanomicrobiales, Methanobacteriales, Methanococcales, and Methanosarcinales.

They are known to be responsible for the production of methane (Demirel \& Scherer, 2008). There are mainly three recognized methanogenic pathways, these being acetoclastic, hydrogenotrophic and methylotrophic pathways (Vanwonterghem et al., 2016). The acetoclastic pathway is an extremely important one for methane production 
$185(70 \%)$ in anaerobic digestion processes (Stams et al., 2012). It is executed by members

186 of the genera Methanosaeta and Methanosarcina, which are known to use acetate for

187 methanogenesis. Methanosaeta is a specialist that uses acetate exclusively,

188 while Methanosarcina is a relative generalist genus that can utilize methanol,

189 methylamine and acetate as well as hydrogen and carbon dioxide for methane

190 production (Guo et al., 2015a). For hydrogenotrophic methanogenesis, members of

191 Methanospirillum, Methanoculleus and Methanoregula genera can reduce $\mathrm{CO}_{2}$

192 successively to methane with $\mathrm{H}_{2}$ as the primary electron donor, and formate through a

193 series of intermediates, including formyl, methylene, and methyl levels. To maintain the

194 stability of anaerobic systems, these species play a crucial role in maintaining the very

195 low partial pressures of $\mathrm{H}_{2}$ necessary for the syntrophic communities of bacteria and

196 archaea to function properly (Stams et al., 2012). Among the above three pathways,

197 methylotrophic methanogens have the smallest number of species belonging to

198 Methanosphaera, Methanococcoides, Methanohalophilus and Methanolobus genera

199 (Vanwonterghem et al., 2016).

200 2. Impacts of antibiotics on the performance of anaerobic processes

201 Anaerobic processes are widely applied to the treatment of swine wastewater

202 (Cheng et al., 2018). However, the inhibition effects of antibiotics on the performance

203 of anaerobic treatment processes have been recently documented (Álvarez et al., 2010;

204 Aydin et al., 2015c; Aydın et al., 2015). As reported earlier (Table 1), the antibiotics

205 reveal a wide range of differences regarding the performance of anaerobic processes.

206 This is due to the variations of antibiotics concentrations and types as well as the

207 combination of different antibiotics (Mitchell et al., 2013; Ozbayram et al., 2015). 


\subsection{Impact on pH}

The level of $\mathrm{pH}$ is an important process parameter during anaerobic treatment processes. It should be noted that both acidogenic and methanogenic micro-organisms have their optimal $\mathrm{pH}$ value. Failing to maintain the optimal range of $\mathrm{pH}(6.7-7.4)$ in the anaerobic reactor could break down the anaerobic systems (Chen et al., 2008; Lay et al., 1997). The presence of antibiotics in the anaerobic reactors could result in the accumulation of VFAs, which would cause a decrease in the $\mathrm{pH}$ value (Beneragama et al., 2013; Ma et al., 2013). For example, Shi et al. (2011) and Aydin et al. (2015b) indicated that the $\mathrm{pH}$ value in reactors with antibiotics decreased more than that in control reactors. In the pig slurry anaerobic digestion process, the $\mathrm{pH}$ of the reactor with chlortetracycline (CTC) was lower than that in the control reactor (Stone et al., 2009).

Additionally, it is notable that the $\mathrm{pH}$ value in the anaerobic reactor was sensitive to high concentrations of antibiotics. As reported by Miller et al. (2013), the $\mathrm{pH}$ value remained stable, which maintained between 7.4 and 7.6 , with the addition of $1-5 \mathrm{mg} / \mathrm{L}$ SMX to the reactor, however, the value of $\mathrm{pH}$ decreased to 6.3 immediately in response to an increase in VFAs after $50 \mathrm{mg} / \mathrm{L}$ of SMX was added. Also demonstrated that the $\mathrm{pH}$ value did not decrease from neutral (6.8-7.2) to 5.9 until the concentration of SMX and tetracycline (TC) was up to 20 and $1.5 \mathrm{mg} / \mathrm{L}$, respectively. Thus, the stability of anaerobic reactors could be effected by adding high concentrations of antibiotics.

However, the sharp decrease of $\mathrm{pH}$ might only happen at the beginning of the anaerobic process with a short contact time between antibiotics and the anaerobic sludge, which would become stable as the reaction progressed. This has been confirmed by the report of Beneragama et al. (2013) and Shi et al. (2011), who stated that the presence of antibiotics (cefazolin and OTC) wielded no effect on the $\mathrm{pH}$ value during anaerobic digestion processes after a sharp decrease of $\mathrm{pH}$ in the beginning. As well, the study 
about effects of antibiotics on anaerobic digestion of swine slurry showed similar results, since the $\mathrm{pH}$ in bioreactors with antibiotics did not show any difference with the control reactors at the end of the treatment cycle (Masse et al., 2000). The reason might be that the short contact time between high concentrations of antibiotic and the anaerobic sludge can promote the organic acid production (acidogens) which results in the accumulation of organic acids due to the failure of methanogens to convert the organic acids to methane (Ma et al., 2013). Such results demonstrate that anaerobic treatment processes are sufficiently buffered to minimize $\mathrm{pH}$ fluctuations and have undergone digestion without a failure.

\subsection{Impact on COD removal efficiencies}

The COD removal efficiency could be affected by the presence of antibiotics in anaerobic treatment processes, which is significantly related to the concentrations of antibiotics (Aydin et al., 2015b). Previous research concluded that removing efficiencies of COD in anaerobic treatment processes can be significantly inhibited by high concentrations of antibiotics. For example, the COD removal efficiency only decreased from $97.8 \pm 2.5 \%$ to $92.9 \pm 1.3 \%$ as the addition of SMX from 1 to $40 \mathrm{mg} / \mathrm{L}$. However, the ASBR system began to collapse when $45 \mathrm{mg} / \mathrm{L}$ of SMX was added with only $25.0 \pm$ $1.1 \%$ of COD elimination (Cetecioglu et al., 2016). Sponza and Demirden (2007) also reported that the COD removal efficiencies in an upflow anaerobic sludge blanket reactor (UASB) reactor only varied from $89 \%$ to $82 \%$ when the sulfamerazine concentration rose from 10 to $65 \mathrm{mg} / \mathrm{L}$. Once the concentration increased to $90 \mathrm{mg} / \mathrm{L}$, only $68 \%$ of COD could be removed.

Meanwhile, tetracycline antibiotics reveal similar inhibition trends with sulfonamide antibiotics in the anaerobic processes. Cetecioglu et al. (2013) indicated that TC had no effect on the removal efficiency of COD in an ASBR reactor with the 
concentration $\leq 5.7 \mathrm{mg} / \mathrm{L}$, while adding higher dose of TC $(8.5 \mathrm{mg} / \mathrm{L})$ in the reactor resulted in a significant inhibition of the overall COD removal efficiencies (only 9\%) compared with that in the control reactor $(\geq 96 \%)$, and the metabolic activity of the biomass could not be reactivated at the end of the operation. Xiong et al. (2017) also reported that the COD concentration in the effluent of the anaerobic process was not affected in the presence of tetracycline with the concentration less than $150 \mu \mathrm{g} / \mathrm{L}$, but increased in greater amounts when adding $20 \mathrm{mg} / \mathrm{L}$ of TC.

Frequently, however, antibiotics are present as mixtures in the environment. The effects of mixtures differ from the individual compounds, due to the antagonistic and/or synergistic effects among them (Ozbayram et al., 2015). For instance, Aydin et al. (2015c), Aydin et al. (2014) and Aydin et al. (2016) indicated that the combination of antibiotics (erythromycin-tetracycline-sulfamethoxazole (ETS), sulfamethoxazoletetracycline (ST), erythromycin-sulfamethoxazole (ES) and erythromycin-tetracycline (ET)) had more serious inhibition than the individual antibiotics on the COD utilization and methane production. As well, the study also indicated that the joint inhibition of combined antibiotic on the performance of anaerobic treatment was more serious at higher concentrations (Aydin et al., 2015b; Aydin et al., 2015c). In particular, Aydin et al. (2015b) concluded that the COD removal efficiency was not significantly affected if the added concentration of SMX and TC mixtures was less than $10 \mathrm{mg} / \mathrm{L}$, whereas, the performance of the reactor declined substantially after $30 \mathrm{mg} / \mathrm{L}$ of the SMX and TC mixture was added to the reactor. The authors also concluded that less than $17 \mathrm{mg} / \mathrm{L}$ of ETS did not exert a noticeable effect on the overall COD removal efficiency, while the effluent soluble COD concentration would increase to more than $2000 \mathrm{mg} / \mathrm{L}$ ( $82 \pm 21.2$ $\mathrm{mg} / \mathrm{L}$ in control reactor), corresponding to an overall COD reduction of only $10 \%$ when $46 \mathrm{mg} / \mathrm{L}$ of ETS were added. What is worse, such inhibition cannot be balanced since 
the metabolic activity of the biomass could not be reactivated to induce noticeable substrate utilisation.

As discussed above, it is notable that the inhibitory influence of antibiotics on the COD removal efficiencies of the anaerobic process resulted in the accumulation of soluble COD in reactors. This is most likely due to the presence of antibiotic stimulated activities of fermentative or acid-forming bacteria in the anaerobic reactors which produce more soluble COD. In addition, the utilization of the soluble COD might decrease due to the inhibition of antibiotics on the interrelated activities of hydrogen producing acetogenic bacteria, methane producing aceticlastic methanogens, and or a combination of all these processes (Stone et al., 2009).

\subsection{Impact on biogas and methane production}

Biogas and methane generation is the inherent outcome of COD removal under anaerobic conditions, their production is parallel to the effluent COD concentration of anaerobic treatment processes. As the terminal end-products produced from biodegradable materials, biogas and methane production is good indicators of digestive performance (Boe et al., 2010). However, the effect of antibiotics on methane and COD might be different. As reported earlier, the addition of TC started to inhibit biogas production with the dosing of $1.65 \mathrm{mg} / \mathrm{L}$ in an ASBR despite achieving complete COD removal. Lu et al. (2016) also reported that the presence of TC $(250 \mu \mathrm{g} / \mathrm{L})$ in an anaerobic baffled reactor (ABR) had less influence on the degradation of organic matter but had a strong influence on biogas generation and the accumulation of VFAs. This might be the reason that the methanogenesis process was sensitive to $\mathrm{TC}$ presence, but the acidogenesis process was insensitive, so that only part of the substrate is utilized for methane production. 
Similarly, there is a wide range of inhibition from complete biogas inhibition to

slight biogas enhancement based on the antibiotic types and concentrations. For example, Sanz et al. (1996) indicated that the presence of penicillin and TC in swine slurries reduced methane production by $35 \%$ and $25 \%$, respectively. However, other antibiotics in slurries from pigs, including tylosin, lyncomycin, sulfamethazine, and carbadox, did not significantly affect methane production. In addition, higher concentrations of antibiotics showed more serious influence on methane production.

This is explained by their bactericidal characteristics that kill bacteria instead of inhibiting bacterial growth at high concentrations, which is very different to bacteriostatic characteristics at lower concentrations (Bauer et al., 2014; Shi et al., 2011). According to the report by Cetecioglu et al. (2015) and Mohring et al. (2009), biogas production was not affected significantly by adding sulfonamide antibiotics (less than $18 \mathrm{mg} / \mathrm{L}$ ) in the anaerobic system; however, the inhibition became noticeable with the concentration of SMX higher than $45 \mathrm{mg} / \mathrm{L}$.

Compared to other types of antibiotics, CTC and OTC showed a relatively serious effect on the biogas and methane production in anaerobic digesters (Wang et al., 2016; Yin et al., 2016). As reported by Sun et al. (2012), CTC was the most significant inhibitor among the antibiotics of CTC, amoxicillin, florfenicol, and sulfamethazine. In contrast, doxycycline (DC) showed less activity and resulted in a $25 \%-45 \%$ reduction on methane production with the concentration of 10-100 mg/L. Stone et al. (2009) stated that the CTC $(27 \mathrm{mg} / \mathrm{L})$ reactor inhibited the production rate of methane and resulted in $27.8 \%$ reduction of total production, although total methane production increased in all anaerobic reactors of swine slurry. Sanz et al. (1996) also revealed that CTC was a powerful inhibiter for acetoclastic methanogenic bacteria with 50\% reduction of methane at $40 \mathrm{mg} / \mathrm{L}$ of CTC concentration. Similar to CTC, 
oxytetracycline (OTC) indicates a significant effect on methane production, and inhibition increased with the growing concentration of OTC (Ince et al., 2013). For instance, Arikan et al. (2006) revealed that OTC could reduce methane production by $27 \%$ even at $3.1 \mathrm{mg} / \mathrm{L}$ in the anaerobic digestion system. Xin et al. (2014) also indicated that the generation rate of methane and total production of biogas during the anaerobic digestion process decreased with the concentrations of OTC stepwise increasing from 0 , 20,50 to $80 \mathrm{mg} / \mathrm{L}$. As well, the methane production fell by $56 \%, 60 \%$ and $62 \%$ at OTC and CTC concentrations of 10,50 and $100 \mathrm{mg} / \mathrm{L}$ during the anaerobic digestion of pig slurry, respectively (Álvarez et al., 2010). Similarly, a highly significant decrease in methane production in the presence of OTC (around $3 \mathrm{mg} / \mathrm{L}$ ) was also observed in twophase and single-phase digesters of cattle manure, with $43 \%$ and $52 \%$ lower than control digesters, respectively. Interestingly, higher methane yields and OTC reductions were achieved with two-phase configuration, due to much higher cell activity was observed than that in single-phase digester (Akyol et al., 2016). This could be explained that CTC and OTC are effective against both gram-negative and gram-positive organisms by inhibiting bacterial protein synthesis through binding to the $30 \mathrm{~S}$ ribosomal subunit. Therefore, at high CTC and OTC concentrations, they would impose a significant inhibition effect on the activity of microorganisms in anaerobic treatment processes (Beneragama et al., 2013; Wang et al., 2016).

As for tylosin, its inhibition behavior was only obvious at higher concentrations. It may be attributed to its limited spectrum of activity toward gram-negative bacteria, although tylosin is active against many gram-positive bacteria (Sanz et al., 1996). In an anaerobic sequencing batch reactor (ASBR), Angenent et al. (2008) and Shimada et al. (2008) both indicated that tylosin at 1.6 and $1.67 \mathrm{mg} / \mathrm{L}$ had negligible effects on the total methane production and propionate degradation, though the rate of both decreased. 
357 Nonetheless, a reduction of methane production occurred after its concentration

358 increased to $167 \mathrm{mg} / \mathrm{L}$, because its high inhibition on propionate- and butyrate-

359 oxidizing syntrophic bacteria and fermenting bacteria resulted in unfavourable effects

360 on methanogenesis. The inhibition of high concentrations of tylosin on the anaerobic

361 treatment process was also confirmed by Mitchell et al. (2013), who wrote that tylosin

362 at a concentration of less than $100 \mathrm{mg} / \mathrm{L}$ did not show any inhibition on the total

363 production of biogas, while as the concentration increased stepwise to $130,260,520$

364 and $913 \mathrm{mg} / \mathrm{L}$, biogas production reduced by $10 \%, 20 \%, 30 \%$ and $38 \%$, respectively.

365 However, penicillin showed inhibitions on the methane production at all concentrations

366 evaluated since this type of antibiotics can inhibit the cell wall synthesis (Rodríguez et

367 al., 2017). Specifically, masse et al. (2000) found that bioreactors with penicillin or TC

368 experienced a significant decrease of methane production ( $35 \%$ and $25 \%$, respectively),

369 with respect to the control ones. Gartiser et al. (2007) also discovered that amoxicillin, a

370 comparable penicillin antibiotic, lowered biogas production by $10 \%$ and $20 \%$ with 12.3

371 and $95.9 \mathrm{mg} / \mathrm{L}$ amoxicillin added in the reactor.

Again, the combination of antibiotics demonstrated higher inhibition on the

methane production than the individual antibiotic. For example, Álvarez et al. (2010)

reported the significant inhibition of anaerobic digestion in the swine slurry containing a

combination of CTC and OTC at concentrations of 10,50 and $100 \mathrm{mg} / \mathrm{L}$; methane

production reduced by $56 \%, 60 \%$ and $62 \%$, respectively. Aydin et al. (2015b) also

reported that the biogas and methane production were almost completely inhibited by

the combined antibiotics of ERY, TC and SMX. The research conducted by Aydin et al.

379 (2015a), Aydin et al. (2015b), and Ozbayram et al. (2015) showed the synergistic and

380 antagonistic effect between different antibiotics. In the mixture of ETS, SMX can have 
almost all antibiotic mixtures that included TC as a component (Aydin et al., 2015b; Aydin et al., 2015).

However, some reports concluded that antibiotics had no or only a limited effect on the production of biogas even at high concentrations (Chelliapan et al., 2011; Mitchell et al., 2013). As described previously, SMX did not inhibit biogas production at $6-100 \mathrm{mg} / \mathrm{L}$ (Gartiser et al., 2007). The author also stated that the reactor with sulfamethazine and ampicillin up to $280 \mathrm{mg} / \mathrm{L}$ and $350 \mathrm{mg} / \mathrm{L}$ exhibited no impact on total biogas production compared with the control reactor, although they did inhibit biogas production rates during early stages of anaerobic digestion. Similarly, Lallai et al. (2002) demonstrated that OTC (125 and 250mg/L) had no varied effect on methane production in the anaerobic digestion of swine slurry in comparison to the control value. They concluded that both the acid-forming and methane-forming microbes were not affected by the presence of OTC. Chelliapan et al. (2011) also found negligible biogas inhibition with 100-800 mg/L tylosin in an up-flow anaerobic stage reactor (UASB). The reason for the above varied results may be attributed to the differences in the histories of sludge used, the acclimatization period, the microbial structures and the operational conditions. Álvarez et al. (2010) reported that the less inhibitive behavior of sulfonamides was due to their reduced antibacterial activity resulting from the large size of fresh inoculum and the complexity of the sludge (inherently including endogenous protein-degradation products). These organic compounds prevented sulfonamides from causing bacteriostasis on susceptible bacteria. It is known that methanogens are responsible for producing methane in an anaerobic treatment process. As advances are made in the anaerobic digestion process, the methanogen populations become more established, which leads to more methane being produced. 
concentrations of antibiotics could be tolerated after a period of adaptation by microbes

408 in anaerobic processes. Nevertheless, certain concentrations of antibiotics would exert some pressure on methanogens at the beginning, so methanogens had to undergo an acclimatization phase (Beneragama et al., 2013). Acclimatization is a selection and multiplication of specialized microorganisms capable of biodegrading or cometabolizing the compounds or only surviving in the presence of relevant compounds after a certain adaptation time. Hence, the acclimatization phase was considered vital for the biodegradation of antibiotics and their impact on the performance of anaerobic treatment processes (Wang et al., 2017b). As a result, the antibiotics might inhibit the recovery or acclimation as time progressed. influential factors in the impact of antibiotics on methane production, and less inhibition antibiotics on the production of methane and treatment efficiency of anaerobic processes, reported by Loftin et al. (2005) and Dreher et al. (2012), might be the consequence of the acclimation experienced by their microbial consortia, since it has

427 adapted to the presence of antibiotics. García-Sánchez et al. (2016) also revealed that

428 for biomass that had no contact with an antibiotic, the presence of tylosin inhibited the 429 generation of methane even at concentrations as small as $0.01 \mathrm{mg} / \mathrm{L}$. Whereas, in the digesters acclimating the presence of tylosin at a concentration of $0.01-0.065 \mathrm{mg} / \mathrm{L}$, 
methanogenesis was not inhibited and the generation of methane improved. It may imply that the microorganisms have developed not only a resistance to the antibiotic but also the ability to metabolize it.

The increasing concentrations of antibiotics do not always cause the elevated inhibition of methane production; conversely, the use of an appropriate dose of antibiotics could aid in enhancing methane production due to their metabolism by microorganisms (Sponza \& Demirden, 2007). The authors indicated a relatively high concentration of sulfamethazine could increase the total amount of methane production. In the UASB reactor, with the addition of 10 and $90 \mathrm{mg} / \mathrm{L}$ of sulfamerazine, the daily methane gas production was recorded as $1558 \mathrm{ml}$ and 2000-2275 $\mathrm{ml}$, respectively, although the maximum methane percentage decreased from $76 \%$ to $60 \%$. Yin et al. (2016), Lu et al. (2014) and Yin et al. (2015) also demonstrated the beneficial role of CTC, OTC, cefalexin and colistin sulfate in methane production in anaerobic treatment. These results might be attributed to the utilization of antibiotics as co-substrates together with glucose-COD, which were used as primary carbon and energy sources for micro-organisms in the anaerobic processes (Sponza \& Demirden, 2007).

\subsection{Impact on the accumulation of VFAs}

VFAs, as short chain fatty acids that include formate, acetate, propionate, butyrate etc., are intermediate and or end products of the anaerobic process. Their accumulation is important for the performance of anaerobic systems (Lins et al., 2015). One research group observed that adding SMX, ERY, and TC at $15-20,1.5$, and $1.5 \mathrm{mg} / \mathrm{L}$ concentrations, respectively, could accumulate $400-600 \mathrm{mg} / \mathrm{L}$ of VFAs (Aydin et al., 2015d). Similarly, Cetecioglu et al. (2015) and Miller et al. (2013) stated that increasing SMX concentration to $45 \mathrm{mg} / \mathrm{L}$ and $50 \mathrm{mg} / \mathrm{L}$ could result in the accumulation of VFAs and the decrease of $\mathrm{pH}$, alkalinity in anaerobic processes. 
Stone et al. (2009) indicated the VFAs accumulation in the CTC (27mg/L) treatment reactor was the greatest about $37.4 \%-47.0 \%$ more than the tylosin and control reactors, and the acetate concentration in the CTC treatment $(12,269 \mathrm{mg} / \mathrm{L})$ was greater than either the tylosin $(7687 \mathrm{mg} / \mathrm{L})$ or the no-antimicrobial control $(6498 \mathrm{mg} / \mathrm{L})$ treatments. This might be the reason that the generation of acetate through soluble organic

fermentation is efficient, however, the utilization of acetate by either homoacetogenic bacteria or aceticlastic methanogens was inhibited by CTC. As well, both propionate and butyrate concentrations in the CTC and tylosin $(1.67 \mathrm{mg} / \mathrm{L})$ treatment reactor were greater than those in control, implying that CTC and tylosin inhibited propionate and butyrate degraders, such as the genera of Pelotomaculum, Psychrobacter and Streptococcus (as shown in Table 2). Similarly, Sanz et al. (1996) also indicated the butyrate degrading bacteria were affected by CTC at low concentration, and died as the concentration of CTC increased above $100 \mathrm{mg} / \mathrm{L}$. This resulted in a greater accumulation of short-chained VFAs during the anaerobic digestion compared to a noantimicrobial control system. The anaerobic reactors with OTC (30, 60, $90 \mathrm{mg} / \mathrm{L})$ also exhibited an increasing trend in the accumulation of total VFAs compared to the control reactor (Beneragama et al., 2013).

The accumulation of VFAs showed a positive correlation with antibiotic concentrations. This has been confirmed by Aydin et al. (2015a), who revealed that the VFAs concentration increased in a linear manner with the increase of antibiotics concentration. Xiong et al. (2017) also indicated that TC had no impact on the accumulation of VFAs with the concentrations less than $150 \mu \mathrm{g} / \mathrm{L}$, while a significant accumulation of VFAs and increase in propionate were observed in the reactor subjected to the highest concentration of TC $(20 \mathrm{mg} / \mathrm{L})$. The accumulation of VFAs 
may result from the stimulation of the acidogenesis and/or the subsequent inhibition of VFAs degradation as well as methanogenic activities (Beneragama et al., 2013).

As well, the effect of a combination of antibiotics in swine wastewater is higher than the effect of the individual antibiotic. For example, Cetecioglu et al. (2012) examined the individual inhibitory effects of antibiotics on the ASBR process. They indicated that the VFA accumulation started from $25 \mathrm{mg} / \mathrm{L}$ within the tetracycline dosage and $250 \mathrm{mg} / \mathrm{L}$ within the SMX and ERY dosage. However, Aydin et al. (2015a) found VFAs started to accumulate even in the presence of very low concentration of antibiotic mixtures (1 mg/L of ET-ST). Their results indicate that antibiotic combinations have an effect on acetate, propionate and butyrate degradation pathways, leading to the accumulation of VFAs and soluble microbial products, which results in a decrease in the total methane production.

In summary, different classes of antibiotics reflect different impacts on the performance of anaerobic treatment processes related to their mode of actions.

Generally, lower dose of antibiotics shows less impact on the stability, the removal efficiencies and the production of biogas and methane in anaerobic processes. In contrast, relatively higher concentrations of antibiotics cause toxic effects on microorganisms in the anaerobic process, affect the substrate removal and the biogas production, and even result in a total collapse of the reactors. The various combinations of antibiotics increase inhibition effects over the individual antibiotics. Additionally, the synergistic and antagonistic effects are also identified in the reactor within the antibiotic mixtures. 


\section{Impact of antibiotics on the microbial communities in anaerobic processes}

The anaerobic system contains a complex microbial culture, and the conversion of organic compounds to methane is carried out by various microbial communities in acidogenic and methnogenic processes (Town et al., 2014). There is a significant correlation between the microbial community (both bacterial and archaeal) and the performance of anaerobic reactors such as COD removal efficiency, biogas production, and VFAs accumulation. Failure to maintain the stability of these microorganisms would result in a decrease in the performance and stability of anaerobic reactors (Aydin et al., 2015e; Beneragama et al., 2013; Cetecioglu et al., 2016). Based on all of the above, we can conclude that the presence of antibiotics has a negative effect on biogas and methane production, yet appears to have a positive effect on the accumulation of VFAs. This indicates that the methanogenesis process is sensitive to the exposure to antibiotics, while the acidogenesis process is not. As reported, the decrease in methane and biogas production was closely related to the disappearance of the acetoclastic methanogens represented by the Methanosarcinales order in the reactor with antibiotics (Aydin et al., 2015e). Venkiteshwaran et al. (2016) and Aydın et al. (2015) did report the change in the composition and diversity of the microbial community was linked to the performance of anaerobic reactors. Hence, in anaerobic treatment processes, a relatively higher balance and diversity in their bacterial communities resulted in a higher biogas and methane production. Nonetheless, the existence of antibiotics in anaerobic systems may change the structure of the microbial community (Xin et al., 2014; Table 2). The reason is that antibiotics in general, even those broad-spectrum medications, have their selective effects on various groups of microbes. As a result, the selective antibiotic effects alter the relative abundance of microbial species, and 
subsequently interfere with the interactions among different species (Wang et al.,

527 2017b).

\section{$528 \quad 3.1$ Impact on the bacteria in anaerobic processes}

529 During the initial phase of anaerobic treatment processes, hydrolytic and

530 fermentative bacteria, belonging to Bacteroidetes, Firmicutes, Thermotogae,

531 Actinobacteria and Spirochaetes phyla (in Fig. 3) showed positive correlation with the

532 presence of antibiotics. For example, Cetecioglu et al. (2016) demonstrated that

533 Clostiridum species in the Firmicutes phylum which were known to produce lactic acid,

534 ethanol and volatile fatty acids, became dominant in the ASBR with SMX. As well, the

535 number of Acinetobacter species increased along with the rising concentration of SMX

536 (Cetecioglu et al., 2016). This may explain why Acinetobacter species were reported as

537 the hosts of sulfonamide resistance genes. Xiong et al. (2017) also found the changes in

538 microbial communities in anaerobic treatment processes when exposed to different

539 concentrations of TC. In the anaerobic reactor with $20 \mathrm{mg} / \mathrm{L}$ of TC, the relative

540 abundance of bacteria belonging to Bacteroidetes, Spirochaetes and Firmicutes phyla

541 increased significantly in comparison with the reactor with $150 \mu \mathrm{g} / \mathrm{L}$ of TC (Xiong et

542 al., 2017). Specifically, the VFAs producing bacteria increased significantly in the

543 reactor with the high concentration of TC, including Clostridium aurantibutyricum,

544 Microbacter margulisiae, Porphyromonas pogonae, Treponema zuelzerae and

545 Proteiniphilum acetatigenes (propionate-producing bacteria). Similarly,

546 Spirochaetaceae, in the phylum Spirochaetes, could ferment glucose to acetate, ethanol,

547 and small amounts of lactate which present an obviously increasing trend during the

548 anaerobic digestion reactors with the addition of CTC (Wang et al., 2017a). The

549 positive effect of antibiotics on some bacteria might relate to the contact time between 
antibiotics and biomass. This was demonstrated by faster growth kinetics and a better adaption rate of antibiotics and the bacteria (Aydin et al., 2015c; Ma et al., 2013).

Yet, a negative relationship between antibiotics and the VFAs degrading bacteria in anaerobic processes was found by previous researchers. Aydin et al. (2016) indicated that Bacteroidetes, Acinetobacter and Proteobacteria were negatively affected by different antibiotic combinations present in the anaerobic reactor compared to the control samples. This is despite the fact that the population of the Firmicutes in the reactor did not significantly change in comparison to the control reactor according to antibiotic concentration (3.0 mg/L). Xin et al. (2014) and Akyol et al. (2016) also reported that the total microbial diversity decreased with the addition of OTC in the anaerobic digestion reactor, and a higher concentration of OTC would decrease the relative abundance of Gammaproteobacteria in Proteobacteria phylum and result in the disappearance of Sphingobacteriaceae in Bacteroidetes phylum, although the genus Flavobacterium revealed great resistance to the increase in antibiotic loadings, and existed throughout the entire digestion process. Bacterial phyla, including Proteobacteria, Cloacimonetes, Ignavibacteriae, and Chloroflexi, showed the significantly less number in the reactor with high concentrations of TC than those in the control reactor (Xiong et al., 2017). According to one study about the acute effects of antibiotics on syntrophic butyrate and propionate-oxidizing bacteria in ASBR, antibiotics could cause inhibitory effects on butyrate and propionate degradation bacteria, including the species of Syntrophomonas, Syntrophospora, Syntrophobacter and Pelotomaculum (Aydin et al., 2015a). As a result, the utilization of VFAs by bacteria is affected by the addition of antibiotics, and the propionic acid utilization is much more affected than butyric acid utilization. 


\subsection{Impact on methanogens in anaerobic processes}

During the methnogenic phase, the impact of antibiotics on the structures of acetogenotrophic, hydrogenotrophic and methylotrophic methanogens could dominate the performance of the whole anaerobic treatment processes. As reported, the presence of antibiotics in the anaerobic reactors had adverse effects on acetogenotrophic methanogens but positive effects on the abundance of hydrogenotrophic methanogens. For instance, Xiong et al. (2017), Cetecioglu et al. (2013) and Wang et al. (2017a) concluded that the long-term exposure of TC and CTC to the anaerobic reactor had negative effects on the relative abundances of acetogenotrophic methanogens like Methanothrix, Methanoculleus, and Methanobacterium genus. However, an increase in the relative abundance of Methanomassiliicoccus and Methanoculleus (hydrogenotrophic methanogens) was observed. Similarly, the abundance of hydrogenotrophic methanogens, especially Methanobacterium species, and methanogenic archeons in the ASBR with the high concentration of SMX (40 mg/L) also became dominant through the operation, while the acetoclastic methanogens disappeared in the last phase (Cetecioglu et al., 2016; Shin et al., 2010). The order Methanomicrobiales, which utilizes hydrogen or formate as electron acceptors to produce methane, is the most abundant methanogenic group in the anaerobic digestion processes with high concentrations of OTC (Wang et al., 2016).

In addition, Aydin et al. (2015e) and Cetecioglu et al. (2015) also reported that the total number of methanogenic population was not affected in the processes with longterm exposure to high concentrations and combined antibiotics, probably due to the shift of the major pathway to hydrogenotrophic methanogenesis. Hydrogenotrophic methanogens were higher in substrate utilization rate, growth rate and cell yield to exposed toxic substances compared to acetoclastic methanogens (Aydin et al., 2015c). 
599 The reason is that the inhibition effect of antibiotics on the acetoclastic methanogens

600 makes homoacetogenic bacteria more competitive to transfer acetate to $\mathrm{H}_{2}$ and $\mathrm{CO}_{2}$, and

601 this procedure would provide a substrate for hydrogenotrophic methanogens to produce

602 methane. Consequently, homoacetogenesis coupled with hydrogenotrophic

603 methanogenesis enables the microbial community to maintain the system's stability

604 (Aydin et al., 2015a; Cetecioglu et al., 2016). The research reported by Aydin et al.

605 (2015c) also confirmed that antibiotic combination did have a dramatic effect on the

606 acetoclastic methanogens present in the ST and ETS reactors. In particular, as the

607 ancestral form of methane production, hydrogenotrophic methanogenesis was

608 reported to be the most widespread in all methanogenic orders (Bapteste et al., 2005).

609 Methanogenic archaea show more tolerance than bacteria when exposed to

610 antibiotics which inhibiting protein synthesis like tetracyclines and macrolides (Aydın

611 et al., 2015). The reason is that archaeal ribosomes have a heterogeneous protein

612 composition, enabling them to adapt to harsh environmental conditions in comparison

613 with bacterial ribosomes (Hilpert et al., 1981). Furthermore, sulfonamides are

614 bacteriostatic inhibitors designed to prevent bacterial infections and therefore reveal a

615 more obvious effect on bacteria than archaea (Aydin et al., 2015e). Thus, both bacteria

616 and methanogenic archaea can be affected by the presence of antibiotics according to

617 the classes and concentrations of antibiotics. Previous research revealed that even

618 though some species in the anaerobic process were negatively affected by higher

619 antibiotic concentrations, the surviving species continued the degradation of substrate

620 and the production of methane (Cetecioglu et al., 2016).

621 4. Future perspectives

622 Anaerobic processes are widely applied to treat wastes from swine farms. So far,

623 studies mainly focused on the occurrence, fate, and removal of antibiotics from swine 
wastewaters through anaerobic processes (Cheng et al., 2018). However, the toxic effect of antibiotics on micro-organisms in anaerobic processes should be given more attention considering the important role of micro-organisms in these processes. In this review, we can see the complicacy of microbial communities responding to antibiotics. Hence, it is important and necessary to study the impact of antibiotics on the treatment process and microorganisms in anaerobic processes, to understand the fate of antibiotics in anaerobic processes, to know the removal mechanism of antibiotics by the anaerobic treatment, and to improve their removal efficiencies from wastewater.

To date, there are still large gaps in our knowledge on the impact of antibiotics on anaerobic processes. Only a few types of antibiotics, such as SMX, TC, CTC, etc., were studied previously, whilst studies on other antibiotics in swine wastewater are very limited. Furthermore, these analyses mainly focused on the potential inhibiting mechanisms of individual antibiotic. However, we should not ignore the fact that antibiotics do not appear in swine wastes individually, but rather together with many other types of antibiotics and toxic pollutants (hormones and/or heavy metals) (Zhang et al., 2017b). The current studies on the impact of the coexistence of different types of antibiotics and metals on the anaerobic treatment processes only touch the tip of the iceberg; much more investigation should be done in the future due to their synergistic and or antagonistic effects (Aydin et al., 2015c; Guo et al., 2012; Zhang et al., 2017a). In addition, only a few studies focused on the impact of the metabolites of antibiotics on micro-organisms in anaerobic processes, and noted their potential toxic effects (Baumann et al., 2015). Thus, further studies are needed to obtain more comprehensive data about the impact of the combination of many antibiotics as well as their metabolites on microbial communities in anaerobic treatment processes. 
648 Furthermore, the proliferation and dissemination of antibiotic resistance genes in

649 the anaerobic swine wastewater treatment process are the most serious threats of

650 antibiotics to the environment and people's health. Therefore, to reduce the threats of

651 antibiotic resistance genes in anaerobic treatment processes, more studies are urgently

652 required to explore the relationship between antibiotics, microorganisms and antibiotic

653 resistance genes.

654 5. Conclusion

655 The key conclusions in this review article are as follows:

656 - Higher doses and combined antibiotics revealed more inhibition effects on

657 anaerobic processes than that of lower concentration and individual antibiotics.

658 - The VFAs degrading bacteria and acetoclastic methanogens were more sensitive

659 to antibiotics than other hydrolytic bacteria, VFAs producing bacteria, and

660 hydrogenotrophic methanogens in the anaerobic processes.

661 Acknowledgement

662 This review research was supported by the Centre for Technology in Water and

663 Wastewater, University of Technology, Sydney (UTS, RIA NGO), Korean Ministry of

664 Environment as a “Global Top Project”, Project No. 201600220005) and Joint Research

665 Centre for Protective Infrastructure Technology and Environmental Green Bioprocess

666 (UTS and Tianjin Chengjian University).

\section{References}

668 1. Akyol, Ç., Ince, O., Cetecioglu, Z., Alkan, F.U., Ince, B. 2016. The fate of

669 oxytetracycline in two-phase and single-phase anaerobic cattle manure digesters and its

670 effects on microbial communities. J. Chem. Technol. Biotechnol., 91(3), 806-814. 
671 2. Ali Shah, F., Mahmood, Q., Maroof Shah, M., Pervez, A., Ahmad Asad, S. 2014.

672 Microbial ecology of anaerobic digesters: the key players of anaerobiosis. Sci. World J.,

6732014.

674 3. Álvarez, J.A., Otero, L., Lema, J., Omil, F. 2010. The effect and fate of antibiotics

675 during the anaerobic digestion of pig manure. Bioresour. Technol., 101(22), 8581-8586.

676 4. Angenent, L.T., Mau, M., George, U., Zahn, J.A., Raskin, L. 2008. Effect of the

677 presence of the antimicrobial tylosin in swine waste on anaerobic treatment. Water Res.,

$678 \quad 42(10), 2377-2384$.

679 5. Ariesyady, H.D., Ito, T., Okabe, S. 2007. Functional bacterial and archaeal

680 community structures of major trophic groups in a full-scale anaerobic sludge digester.

681 Water Res., 41(7), 1554-1568.

682 6. Arikan, O.A., Sikora, L.J., Mulbry, W., Khan, S.U., Rice, C., Foster, G.D. 2006. The

683 fate and effect of oxytetracycline during the anaerobic digestion of manure from

684 therapeutically treated calves. Process Biochem., 41(7), 1637-1643.

685 7. Aydin, S., Cetecioglu, Z., Arikan, O., Ince, B., Ozbayram, E.G., Ince, O. 2015a.

686 Inhibitory effects of antibiotic combinations on syntrophic bacteria, homoacetogens and

687 methanogens. Chemosphere, 120, 515-520.

688 8. Aydin, S., Ince, B., Cetecioglu, Z., Arikan, O., Ozbayram, E.G., Shahi, A., Ince, O.

689 2015b. Combined effect of erythromycin, tetracycline and sulfamethoxazole on

690 performance of anaerobic sequencing batch reactors. Bioresour. Technol., 186, 207-214.

691 9. Aydin, S., Ince, B., Cetecioglu, Z., Ozbayram, E., Shahi, A., Okay, O., Arikan, O.,

692 Ince, O. 2014. Performance of anaerobic sequencing batch reactor in the treatment of

693 pharmaceutical wastewater containing erythromycin and sulfamethoxazole mixture.

694 Water Sci. Technol., 70(10), 1625-1632. 
695 10. Aydin, S., Ince, B., Ince, O. 2015c. Application of real-time PCR to determination

696 of combined effect of antibiotics on Bacteria, Methanogenic Archaea, Archaea in

697 anaerobic sequencing batch reactors. Water Res., 76, 88-98.

698 11. Aydin, S., Ince, B., Ince, O. 2016. Assessment of anaerobic bacterial diversity and

699 its effects on anaerobic system stability and the occurrence of antibiotic resistance

700 genes. Bioresour. Technol., 207, 332-338.

701 12. Aydin, S., Ince, B., Ince, O. 2015d. Development of antibiotic resistance genes in

702 microbial communities during long-term operation of anaerobic reactors in the

703 treatment of pharmaceutical wastewater. Water Res., 83, 337-344.

704 13. Aydın, S., Ince, B., Ince, O. 2015. Inhibitory effect of erythromycin, tetracycline

705 and sulfamethoxazole antibiotics on anaerobic treatment of a pharmaceutical

706 wastewater. Water Sci. Technol., 71(11), 1620-1628.

707 14. Aydin, S., Shahi, A., Ozbayram, E.G., Ince, B., Ince, O. 2015e. Use of PCR-DGGE

708 based molecular methods to assessment of microbial diversity during anaerobic

709 treatment of antibiotic combinations. Bioresour. Technol., 192, 735-740.

710 15. Bapteste, É., Brochier, C., Boucher, Y. 2005. Higher-level classification of the

711 Archaea: evolution of methanogenesis and methanogens. Archaea, 1(5), 353-363.

712 16. Bauer, A., Lizasoain, J., Nettmann, E., Bergmann, I., Mundt, K., Klocke, M.,

713 Rincón, M., Amon, T., Piringer, G. 2014. Effects of the antibiotics chlortetracycline and

714 enrofloxacin on the anaerobic digestion in continuous experiments. Bioenergy Res.,

$715 \quad 7(4), 1244-1252$.

716 17. Baumann, M., Weiss, K., Maletzki, D., Schüssler, W., Schudoma, D., Kopf, W.,

717 Kühnen, U. 2015. Aquatic toxicity of the macrolide antibiotic clarithromycin and its

718 metabolites. Chemosphere, 120, 192-198. 
719 18. Beneragama, N., Lateef, S.A., Iwasaki, M., Yamashiro, T., Umetsu, K. 2013. The

720

721

722

723

724

725

726

727

728

729

730

731

732

733

734

735

736

737

738

739

740

741

742

combined effect of cefazolin and oxytertracycline on biogas production from

thermophilic anaerobic digestion of dairy manure. Bioresour. Technol., 133, 23-30.

19. Blumer-Schuette, S.E., Kataeva, I., Westpheling, J., Adams, M.W., Kelly, R.M.

2008. Extremely thermophilic microorganisms for biomass conversion: status and

prospects. Curr. Opin. Biotechnol., 19(3), 210-217.

20. Boe, K., Batstone, D.J., Steyer, J.-P., Angelidaki, I. 2010. State indicators for

monitoring the anaerobic digestion process. Water Res., 44(20), 5973-5980.

21. Cetecioglu, Z., Ince, B., Gros, M., Rodriguez-Mozaz, S., Barceló, D., Ince, O.,

Orhon, D. 2015. Biodegradation and reversible inhibitory impact of sulfamethoxazole

on the utilization of volatile fatty acids during anaerobic treatment of pharmaceutical

industry wastewater. Sci. Total Environ., 536, 667-674.

22. Cetecioglu, Z., Ince, B., Gros, M., Rodriguez-Mozaz, S., Barceló, D., Orhon, D., Ince, O. 2013. Chronic impact of tetracycline on the biodegradation of an organic substrate mixture under anaerobic conditions. Water Res., 47(9), 2959-2969.

23. Cetecioglu, Z., Ince, B., Orhon, D., Ince, O. 2012. Acute inhibitory impact of antimicrobials on acetoclastic methanogenic activity. Bioresour. Technol., 114, 109116.

24. Cetecioglu, Z., Ince, B., Orhon, D., Ince, O. 2016. Anaerobic sulfamethoxazole degradation is driven by homoacetogenesis coupled with hydrogenotrophic methanogenesis. Water Res., 90, 79-89.

25. Chelliapan, S., Wilby, T., Sallis, P., Yuzir, A. 2011. Tolerance of the antibiotic Tylosin on treatment performance of an Up-flowAnaerobic Stage Reactor (UASR). Water Sci. Technol., 63(8), 1599-1606. 
743 26. Chen, Y., Cheng, J.J., Creamer, K.S. 2008. Inhibition of anaerobic digestion

744 process: a review. Bioresour. Technol., 99(10), 4044-4064.

745 27. Cheng, D.L., Ngo, H.H., Guo, W.S., Liu, Y.W., Zhou, J.L., Chang, S.W., Nguyen,

746 D.D., Bui, X.T. \& Zhang, X.B. 2018, Bioprocessing for elimination antibiotics and

747 hormones from swine wastewater, Sci. Total Environ., vol. 621, pp. 1664-82.

748 28. Demirel, B., Scherer, P. 2008. The roles of acetotrophic and hydrogenotrophic

749 methanogens during anaerobic conversion of biomass to methane: a review. Rev.

750 Environ. Sci. Biotechnol., 7(2), 173-190.

751 29. Dreher, T.M., Mott, H.V., Lupo, C.D., Oswald, A.S., Clay, S.A., Stone, J.J. 2012.

752 Effects of chlortetracycline amended feed on anaerobic sequencing batch reactor

753 performance of swine manure digestion. Bioresour. Technol., 125, 65-74.

754 30. García-Sánchez, L., Garzón-Zúñiga, M.A., Buelna, G., Estrada-Arriaga, E.B. 2016.

755 Tylosin effect on methanogenesis in an anaerobic biomass from swine wastewater

756 treatment. Water Sci. Technol., 73(2), 445-452.

757 31. Gartiser, S., Urich, E., Alexy, R., Kümmerer, K. 2007. Anaerobic inhibition and

758 biodegradation of antibiotics in ISO test schemes. Chemosphere, 66(10), 1839-1848.

759 32. González-Fernández, C., García-Encina, P.A. 2009. Impact of substrate to inoculum

760 ratio in anaerobic digestion of swine slurry. Biomass Bioenergy, 33(8), 1065-1069.

761 33. Guo, J., Ostermann, A., Siemens, J., Dong, R., Clemens, J. 2012. Short term effects

762 of copper, sulfadiazine and difloxacin on the anaerobic digestion of pig manure at low

763 organic loading rates. Waste Manage., 32(1), 131-136.

764 34. Guo, J., Peng, Y., Ni, B.J., Han, X., Fan, L., Yuan, Z. 2015a. Dissecting microbial

765 community structure and methane-producing pathways of a full-scale anaerobic reactor

766 digesting activated sludge from wastewater treatment by metagenomic sequencing.

767 Microb. Cell Fact., 14(1), 33. 
35. Guo, M., Song, W., Buhain, J. 2015b. Bioenergy and biofuels: History, status, and perspective. Renew.Sust. Energ.Rev., 42, 712-725.

36. Hilpert, R., Winter, J., Hammes, W., Kandler, O. 1981. The sensitivity of archaebacteria to antibiotics. Zentralblatt für Bakteriologie Mikrobiologie und Hygiene: I. Abt. Originale C: Allgemeine, angewandte und ökologische Mikrobiologie, 2(1), 1120.

37. Hong, Y.-L., Hossler, P.A., Calhoun, D.H., Meshnick, S.R. 1995. Inhibition of recombinant Pneumocystis carinii dihydropteroate synthetase by sulfa drugs. Antimicrob. Agents Chemother., 39(8), 1756-1763.

38. Huang, L., Wen, X., Wang, Y., Zou, Y., Ma, B., Liao, X., Liang, J., Wu, Y. 2014. Effect of the chlortetracycline addition method on methane production from the anaerobic digestion of swine wastewater. J. Environ. Sci., 26(10), 2001-2006. 39. Ince, B., Coban, H., Turker, G., Ertekin, E., Ince, O. 2013. Effect of oxytetracycline on biogas production and active microbial populations during batch anaerobic digestion of cow manure. Bioprocess Biosystems Eng., 36(5), 541-546.

40. Ji, J.-Y., Xing, Y.-J., Ma, Z.-T., Zhang, M., Zheng, P. 2013. Acute toxicity of pharmaceutical wastewaters containing antibiotics to anaerobic digestion treatment. Chemosphere, 91(8), 1094-1098.

41. Kapoor, G., Saigal, S., Elongavan, A. 2017. Action and resistance mechanisms of antibiotics: A guide for clinicians. J. Anaesthesiol. Clin. Pharmacol., 33(3), 300.

42. Kohanski, M.A., Dwyer, D.J., Collins, J.J. 2010. How antibiotics kill bacteria: from targets to networks. Nat. Rev. Microbiol., 8(6), 423-435.

43. Lallai, A., Mura, G., Onnis, N. 2002. The effects of certain antibiotics on biogas production in the anaerobic digestion of pig waste slurry. Bioresour. Technol., 82(2), 205-208. 
44. Lang, K., Schuldes, J., Klingl, A., Poehlein, A., Daniel, R., Brune, A. 2015. New

mode of energy metabolism in the seventh order of methanogens as revealed by comparative genome analysis of "Candidatus Methanoplasma termitum”. Appl.

Environ. Microbiol., 81(4), 1338-1352.

45. Lay, J., Li, Y., Noike, T., Endo, J., Ishimoto, S. 1997. Analysis of environmental factors affecting methane production from high-solids organic waste. Water Sci. Technol., 36(6-7), 493-500.

46. Li, X., Guo, P., Shan, Y., Ke, Y., Li, H., Fu, Q., Wang, Y., Liu, T., Xia, X. 2017.

Determination of 82 veterinary drugs in swine waste lagoon sludge by ultra-high performance liquid chromatography-tandem mass spectrometry. J. Chromatogr., 1499, $57-64$.

47. Lins, P., Reitschuler, C., Illmer, P. 2015. Impact of several antibiotics and 2bromoethanesulfonate on the volatile fatty acid degradation, methanogenesis and community structure during thermophilic anaerobic digestion. Bioresour. Technol., 190, 148-158.

48. Loftin, K.A., Henny, C., Adams, C.D., Surampali, R., Mormile, M.R. 2005.

Inhibition of microbial metabolism in anaerobic lagoons by selected sulfonamides, tetracyclines, lincomycin, and tylosin tartrate. Environ. Toxicol. Chem., 24(4), 782-788. 49. Lu, M., Niu, X., Liu, W., Zhang, J., Wang, J., Yang, J., Wang, W., Yang, Z. 2016. Biogas generation in anaerobic wastewater treatment under tetracycline antibiotic pressure. Sci. Rep., 6.

50. Lu, X., Zhen, G., Liu, Y., Hojo, T., Estrada, A.L., Li, Y.-Y. 2014. Long-term effect of the antibiotic cefalexin on methane production during waste activated sludge anaerobic digestion. Bioresour. Technol., 169, 644-651. 
51. Ma, J., Frear, C., Wang, Z.-w., Yu, L., Zhao, Q., Li, X., Chen, S. 2013. A simple methodology for rate-limiting step determination for anaerobic digestion of complex substrates and effect of microbial community ratio. Bioresour. Technol., 134, 391-395. 52. Masse, D.I., Lu, D., Masse, L., Droste, R. 2000. Effect of antibiotics on psychrophilic anaerobic digestion of swine manure slurry in sequencing batch reactors. Bioresour. Technol., 75(3), 205-211.

53. McInerney, M.J., Sieber, J.R., Gunsalus, R.P. 2009. Syntrophy in anaerobic global carbon cycles. Curr. Opin. Biotechnol., 20(6), 623-632.

54. Miller, J.H., Novak, J.T., Knocke, W.R., Young, K., Hong, Y., Vikesland, P.J., Hull, M.S., Pruden, A. 2013. Effect of silver nanoparticles and antibiotics on antibiotic resistance genes in anaerobic digestion. Water Environ. Res., 85(5), 411-421.

55. Mitchell, S.M., Ullman, J.L., Teel, A.L., Watts, R.J., Frear, C. 2013. The effects of the antibiotics ampicillin, florfenicol, sulfamethazine, and tylosin on biogas production and their degradation efficiency during anaerobic digestion. Bioresour. Technol., 149, 244-252.

56. Mohring, S.A., Strzysch, I., Fernandes, M.R., Kiffmeyer, T.K., Tuerk, J., Hamscher, G. 2009. Degradation and elimination of various sulfonamides during anaerobic fermentation: a promising step on the way to sustainable pharmacy? Environ. Sci. Technol., 43(7), 2569-2574.

57. Moses, A., Tomaselli, P. 2017. Industrial Animal Agriculture in the United States: Concentrated Animal Feeding Operations (CAFOs). in: International Farm Animal, Wildlife and Food Safety Law, Springer, pp. 185-214.

58. Ocampo, P.S., Lázár, V., Papp, B., Arnoldini, M., Zur Wiesch, P.A., Busa-Fekete, R., Fekete, G., Pál, C., Ackermann, M., Bonhoeffer, S. 2014. Antagonism between 
bacteriostatic and bactericidal antibiotics is prevalent. Antimicrob. Agents Chemother., 58(8), 4573-4582.

59. Ozbayram, E.G., Arikan, O., Ince, B., Cetecioglu, Z., Aydin, S., Ince, O. 2015.

Acute effects of various antibiotic combinations on acetoclastic methanogenic activity.

Environmental Science and Pollution Research, 22(8), 6230-6235.

60. Poels, J., Van Assche, P., Verstraete, W. 1984. Effects of disinfectants and antibiotics on the anaerobic digestion of piggery waste. Agricultural wastes, 9(4), 239247.

61. Ramirez, C., Köpke, A., Yang, D., Boeckh, T., Matheso, A. 1993. The structure, function and evolution of archaeal ribosomes. New Compr. Biochem., 26, 439-466. 62. Rodríguez, D.C., Londoño, Y.A., Peñuela, G.A. 2017. Application of batch tests to assess antibiotic loads in anaerobic processes. Water Sci. Technol., 75(10), 2412-2421. 63. Sánchez-Andrea, I., Sanz, J.L., Stams, A.J. 2014. Microbacter margulisiae gen. nov., sp. nov., a propionigenic bacterium isolated from sediments of an acid rock drainage pond. Int. J. Syst. Evol. Microbiol., 64(12), 3936-3942.

64. Sanz, J., Rodriguez, N., Amils, á.R. 1996. The action of antibiotics on the anaerobic digestion process. Appl. Microbiol. Biotechnol., 46(5), 587-592.

65. Schink, B. 1997. Energetics of syntrophic cooperation in methanogenic degradation. Microbiol. Mol. Biol. Rev., 61(2), 262-280.

66. Shi, J.C., Liao, X.D., Wu, Y.B., Liang, J. 2011. Effect of antibiotics on methane arising from anaerobic digestion of pig manure. Anim. Feed Sci. Technol., 166, 457463.

67. Shimada, T., Zilles, J.L., Morgenroth, E., Raskin, L. 2008. Inhibitory effects of the macrolide antimicrobial tylosin on anaerobic treatment. Biotechnol. Bioeng., 101(1), 73-82. 
866

867

868

869

870

871

872

873

874

875

876

877

878

879

880

881

882

883

884

885

886

887

888

68. Shin, S.G., Lee, S., Lee, C., Hwang, K., Hwang, S. 2010. Qualitative and

quantitative assessment of microbial community in batch anaerobic digestion of secondary sludge. Bioresour. Technol., 101(24), 9461-9470.

69. Sponza, D.T., Demirden, P. 2007. Treatability of sulfamerazine in sequential upflow anaerobic sludge blanket reactor (UASB)/completely stirred tank reactor (CSTR) processes. Sep. Purif. Technol., 56(1), 108-117.

70. Stams, A.J., Sousa, D.Z., Kleerebezem, R., Plugge, C.M. 2012. Role of syntrophic microbial communities in high-rate methanogenic bioreactors. Water Sci. Technol., 66(2), 352-362.

71. Stone, J.J., Clay, S.A., Zhu, Z., Wong, K.L., Porath, L.R., Spellman, G.M. 2009.

Effect of antimicrobial compounds tylosin and chlortetracycline during batch anaerobic swine manure digestion. Water Res., 43(18), 4740-4750.

72. Suhadolnik, M.L., Salgado, A.P., Scholte, L.L., Bleicher, L., Costa, P.S., Reis, M.P., Dias, M.F., Ávila, M.P., Barbosa, F.A., Chartone-Souza, E. 2017. Novel arsenictransforming bacteria and the diversity of their arsenic-related genes and enzymes arising from arsenic-polluted freshwater sediment. Sci. Rep., 7(1), 11231.

73. Sui, Q., Zhang, J., Tong, J., Chen, M., Wei, Y. 2017. Seasonal variation and removal efficiency of antibiotic resistance genes during wastewater treatment of swine farms. Environ. Sci. Pollut. Res., 24(10), 9048-9057.

74. Sun, J., Li, W., Zheng, P., Zhu, J. 2012. Toxicity Evaluation of Antibiotics in Piggery Wastewater by Luminescent Bacteria. Pol. J. Environ. Stud., 21(3). 75. Tenover, F.C. 2006. Mechanisms of antimicrobial resistance in bacteria. Am. J. Med., 119(6), S3-S10. 
889 76. Tong, L., Li, P., Wang, Y., Zhu, K. 2009. Analysis of veterinary antibiotic residues

890 in swine wastewater and environmental water samples using optimized SPE-

891 LC/MS/MS. Chemosphere, 74(8), 1090-1097.

892 77. Town, J.R., Links, M.G., Fonstad, T.A., Dumonceaux, T.J. 2014. Molecular

893 characterization of anaerobic digester microbial communities identifies microorganisms

894 that correlate to reactor performance. Bioresour. Technol., 151, 249-257.

895 78. van de Werken, H.J., Verhaart, M.R., VanFossen, A.L., Willquist, K., Lewis, D.L.,

896 Nichols, J.D., Goorissen, H.P., Mongodin, E.F., Nelson, K.E., van Niel, E.W. 2008.

897 Hydrogenomics of the extremely thermophilic bacterium Caldicellulosiruptor

898 saccharolyticus. Appl. Environ. Microbiol., 74(21), 6720-6729.

899 79. Vanwonterghem, I., Evans, P.N., Parks, D.H., Jensen, P.D., Woodcroft, B.J.,

900 Hugenholtz, P., Tyson, G.W. 2016. Methylotrophic methanogenesis discovered in the

901 archaeal phylum Verstraetearchaeota. Nat. Microbiol., 1, 16170.

902 80. Venkiteshwaran, K., Bocher, B., Maki, J., Zitomer, D. 2016. Relating anaerobic

903 digestion microbial community and process function. Microbiol. Insights, 2015(Suppl.

904 2), 37-44.

905 81. Walsh, C. 2003. Antibiotics: actions, origins, resistance. American Society for

906 Microbiology (ASM).

907 82. Wang, R., Zhang, J., Liu, J., Yu, D., Zhong, H., Wang, Y., Chen, M., Tong, J., Wei,

908 Y. 2017a. Effects of chlortetracycline, $\mathrm{Cu}$ and their combination on the performance

909 and microbial community dynamics in swine manure anaerobic digestion. J. Environ.

910 Sci..

911 83. Wang, S., Hou, X., Su, H. 2017b. Exploration of the relationship between biogas

912 production and microbial community under high salinity conditions. Sci. Rep., 7(1), 9131149. 
84. Wang, X., Pan, H., Gu, J., Qian, X., Gao, H., Qin, Q. 2016. Effects of

915

916

917

918

919

920

921

922

923

924

925

926

927

928

929

930

931

932

933

934

935

936

937

oxytetracycline on archaeal community, and tetracycline resistance genes in anaerobic co-digestion of pig manure and wheat straw. Environ. Technol., 37(24), 3177-3185.

85. Wei, R., Ge, F., Huang, S., Chen, M., Wang, R. 2011. Occurrence of veterinary antibiotics in animal wastewater and surface water around farms in Jiangsu Province, China. Chemosphere, 82(10), 1408-1414.

86. Xin, K., WANG, C.-y., LI, R.-d., ZHANG, Y. 2014. Effects of oxytetracycline on methane production and the microbial communities during anaerobic digestion of cow manure. J. Integr. Agric., 13(6), 1373-1381.

87. Xiong, Y., Harb, M., Hong, P.Y. 2017. Performance and microbial community variations of anaerobic digesters under increasing tetracycline concentrations. Appl. Microbiol. Biotechnol., 1-13.

88. Yang, Y., Yu, K., Xia, Y., Lau, F.T., Tang, D.T., Fung, W.C., Fang, H.H., Zhang, T. 2014. Metagenomic analysis of sludge from full-scale anaerobic digesters operated in municipal wastewater treatment plants. Appl. Microbiol. Biotechnol., 98(12), 57095718.

89. Yin, F., Dong, H., Ji, C., Tao, X., Chen, Y. 2016. Effects of anaerobic digestion on chlortetracycline and oxytetracycline degradation efficiency for swine manure. Waste Manage., 56, 540-546.

90. Yin, F., Wang, D., Li, Z., Ohlsen, T., Hartwig, P., Czekalla, S. 2015. Study on anaerobic digestion treatment of hazardous colistin sulphate contained pharmaceutical sludge. Bioresour. Technol., 177, 188-193.

91. Zhang, R., Gu, J., Wang, X., Qian, X., Duan, M., Sun, W., Zhang, Y., Li, H., Li, Y. 2017a. Relationships between sulfachloropyridazine sodium, zinc, and sulfonamide 
938 resistance genes during the anaerobic digestion of swine manure. Bioresour. Technol., $939 \quad 225,343-348$.

940 92. Zhang, R., Wang, X., Gu, J., Zhang, Y. 2017b. Influence of zinc on biogas

941 production and antibiotic resistance gene profiles during anaerobic digestion of swine 942 manure. Bioresour. Technol., 244, 63-70.

943

944

945

946

947

948

949

950

951

952

953

954 Figure Captions

955 Fig. 1 Classes and antimicrobial mechanisms of antibiotics in swine wastewater

956 Fig. 2 Phases of the anaerobic digestion process

957 Fig.3 Microorganisms ((a) bacteria; (b) methanogens) and their functions in anaerobic 958 process 


\section{Table Captions}

961 Table 1 Impact of antibiotics on the performance of anaerobic treatment processes

962 Table 2 Impact of antibiotics on the microbial communities in anaerobic processes

963

964

965

966

967

968

969

970

971

972

973

974

975

976

977

978

979

980

981 


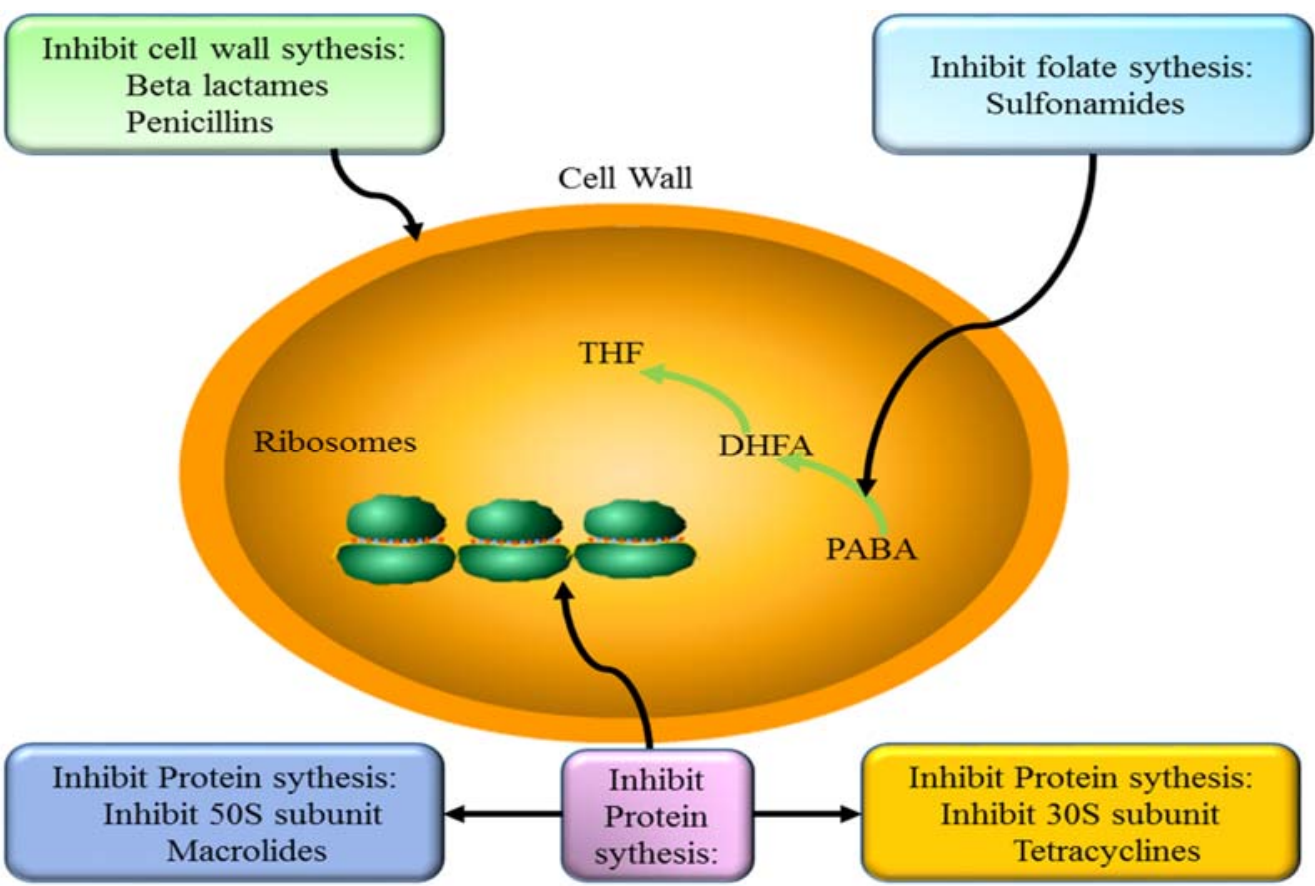

Fig. 1 Classes and antimicrobial mechanisms of antibiotics in swine wastewater

984

988

989

990

991

992

993

994

995 


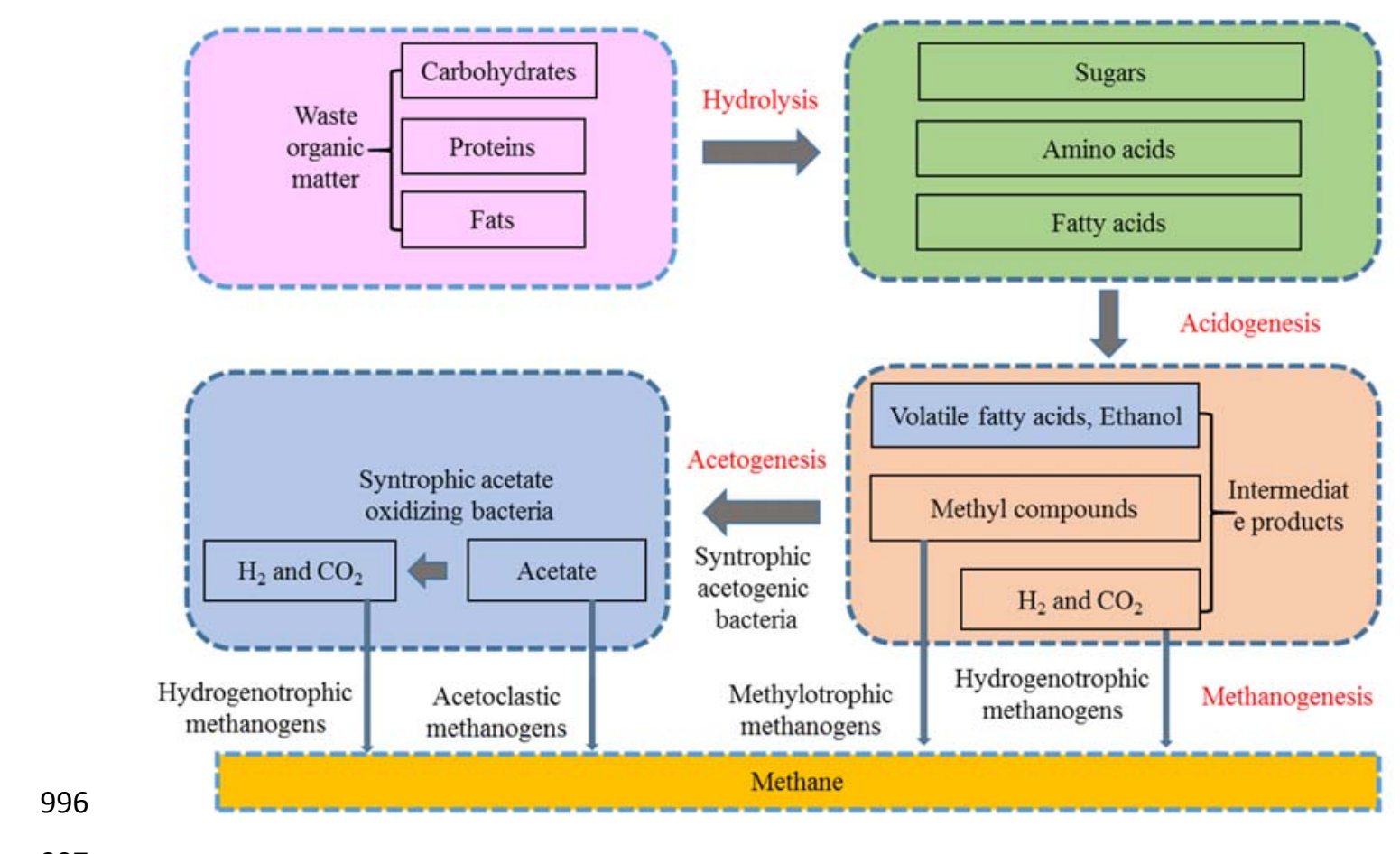

997

998

Fig. 2 Phases of the anaerobic digestion process

999

1000

1001

1002

1003

1004

1005

1006

1007

1008

1009

1010

1011

1012

1013 

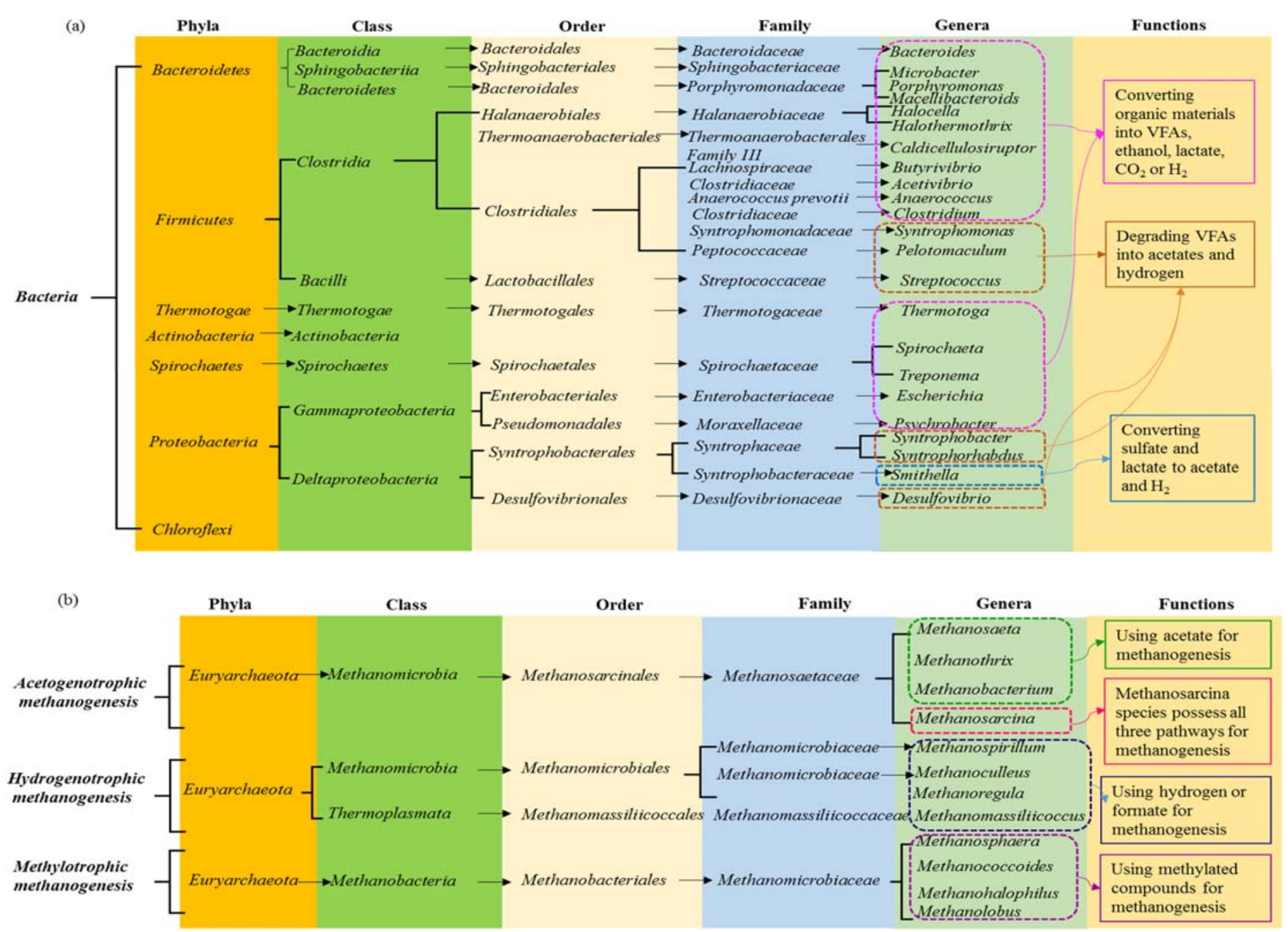

Fig.3 Microorganisms ((a) bacteria; (b) methanogens) and their functions in anaerobic processes 
Table 1 Impact of antibiotics on the performance of anaerobic treatment processes

\begin{tabular}{|c|c|c|c|c|c|}
\hline \multirow[b]{2}{*}{ Antibiotic } & \multirow{2}{*}{$\begin{array}{l}\text { Concentrations } \\
(\mathrm{mg} / \mathrm{L})\end{array}$} & \multicolumn{3}{|c|}{ Effects } & \multirow[b]{2}{*}{ References } \\
\hline & & $\begin{array}{l}\text { COD removal } \\
\text { efficiencies }\end{array}$ & Biogas/methane production & $\begin{array}{l}\text { VFAs accumulation } \\
(\mathrm{mg} / \mathrm{L})\end{array}$ & \\
\hline Sulfamethoxazo & $1-45$ & $\begin{array}{l}96.8 \pm 2.6 \%-25.0 \\
\pm 1.1 \%\end{array}$ & $\begin{array}{l}\text { Biogas: } 1004 \pm 129 \mathrm{~mL} / \mathrm{d}-96 \\
\mathrm{~mL} / \mathrm{d}\end{array}$ & $\begin{array}{l}\text { Propionic acid : not } \\
\text { detected-438; Acetic } \\
\text { acid: not detected-342 }\end{array}$ & (Cetecioglu et al., 2016) \\
\hline & $6-100$ & - & No inhibition & - & (Gartiser et al., 2007) \\
\hline Sulfamerazine & $10-90$ & $88 \%-68 \%$ & Methane content: $76 \%-60 \%$ & $200-600$ & $\begin{array}{l}\text { (Sponza \& Demirden, } \\
2007)\end{array}$ \\
\hline & $\leqslant 280$ & - & $\begin{array}{l}\text { No impact on total biogas } \\
\text { production }\end{array}$ & - & (Mitchell et al., 2013) \\
\hline Sulfamethazine & $5.0-160$ & - & Inhibited & Accumulated & (Sun et al., 2012) \\
\hline Tetracycline & $1.65-5.7-8.5$ & $96 \%-9 \%-0 \%$ & Biogas: 951-853-71 mL/day & $\begin{array}{l}\text { Acetic acid: not } \\
\text { detected-457; Propionic }\end{array}$ & (Cetecioglu et al., 2013) \\
\hline
\end{tabular}


acid: not detected-

(750-385); Butyric

acid: 4-20; Valeric

acid: $14-70$

propionic acid: 0.7-44 (Xiong et al., 2017)

Not statistically

$25 \%$ reduction of methane

affected

pig diet

Decreased

Increased

pig slurry

28

Decreased

$27.8 \%$ reduction of methane

$50 \%$ reduction of methane

Reduce biogas production by

$9.9,10.4$, and $14.1 \%$

$79.1,70.3,68.6 \%$ of the

control values
(Masse et al., 2000)

affected

Accumulated

(Wang et al., 2017a)

Accumulated

(Stone et al., 2009)

(Sanz et al., 1996)

(Wang et al., 2016)

(Beneragama et al.,

Increased 
Oxytetracycline

Chlortetracyclin

10,50 and 100

Tylosin

130, 260, 520,

913

Amoxicillin

60,120

$12.3,95.9$
125,250 $-$

3.1

No significant

effect

No inhibition

(Lallai et al., 2002)

Reduce methane production by

$27 \%$

(Arikan et al., 2006)

Reduced methane production

by 56,60 and $62 \%$

(Álvarez et al., 2010)

Reduced biogas production by

$10,20,30,38 \%$

(Mitchell et al., 2013)

Negligible effects

1.67-167 to completely

inhibited

Negligible effects to

completely inhibited

Accumulated

(Shimada et al., 2008)

(Lallai et al., 2002)

Reduced biogas production by

$10 \%$ and $20 \%$

(Gartiser et al., 2007) 


\begin{tabular}{|c|c|c|c|c|c|}
\hline Penicillin & $\begin{array}{l}16 \mathrm{mg} / \mathrm{kg} \text { used } \\
\text { in pig diets }\end{array}$ & $\begin{array}{l}\text { No statistically } \\
\text { affected }\end{array}$ & $\begin{array}{l}35 \% \text { reductuin of methane } \\
\text { production }\end{array}$ & not statistically affected & (Masse et al., 2000) \\
\hline \multicolumn{6}{|l|}{ Erythromycin- } \\
\hline $\begin{array}{l}\text { Tetracycline } \\
(\mathrm{ET})\end{array}$ & $\begin{array}{l}(0.1+0.1)- \\
(3+3)\end{array}$ & $90 \%-12 \%$ & $\begin{array}{l}\text { Production rate decreased by } \\
\text { more than } 97 \%\end{array}$ & & (Aydin et al., 2016) \\
\hline combinations & & & & & \\
\hline Sulfamethoxazo & $20+1.5$ & Decreased & - & - & (Aydin et al., 2015c) \\
\hline le-Tetracycline & $12-43$ & $80 \%-10 \%$ & $\begin{array}{l}\text { Biogas production: } 1247 \\
\mathrm{~mL} / \text { day }-0\end{array}$ & - & (Aydin et al., 2015b) \\
\hline Sulfamethoxazo & $2.5+2.5+25$ & Decreased & - & - & (Aydin et al., 2015c) \\
\hline le - & & & Biogas production: 1247 & & \\
\hline $\begin{array}{l}\text { Erythromycin - } \\
\text { Tetracycline }\end{array}$ & $18-46$ & $75 \%-10 \%$ & $\begin{array}{l}\mathrm{mL} / \text { day }-0 ; \text { methane yield } \\
\text { dropped from } 0.32 \mathrm{~L} / \mathrm{g} \text { COD }\end{array}$ & $\begin{array}{l}\text { Acetic acid : 50-1000; } \\
\text { Butyric acid: } 140-710\end{array}$ & (Aydin et al., 2015b) \\
\hline & & & removed to 0 & & \\
\hline
\end{tabular}


Table 2 Impact of antibiotics on the microbial communities in anaerobic processes

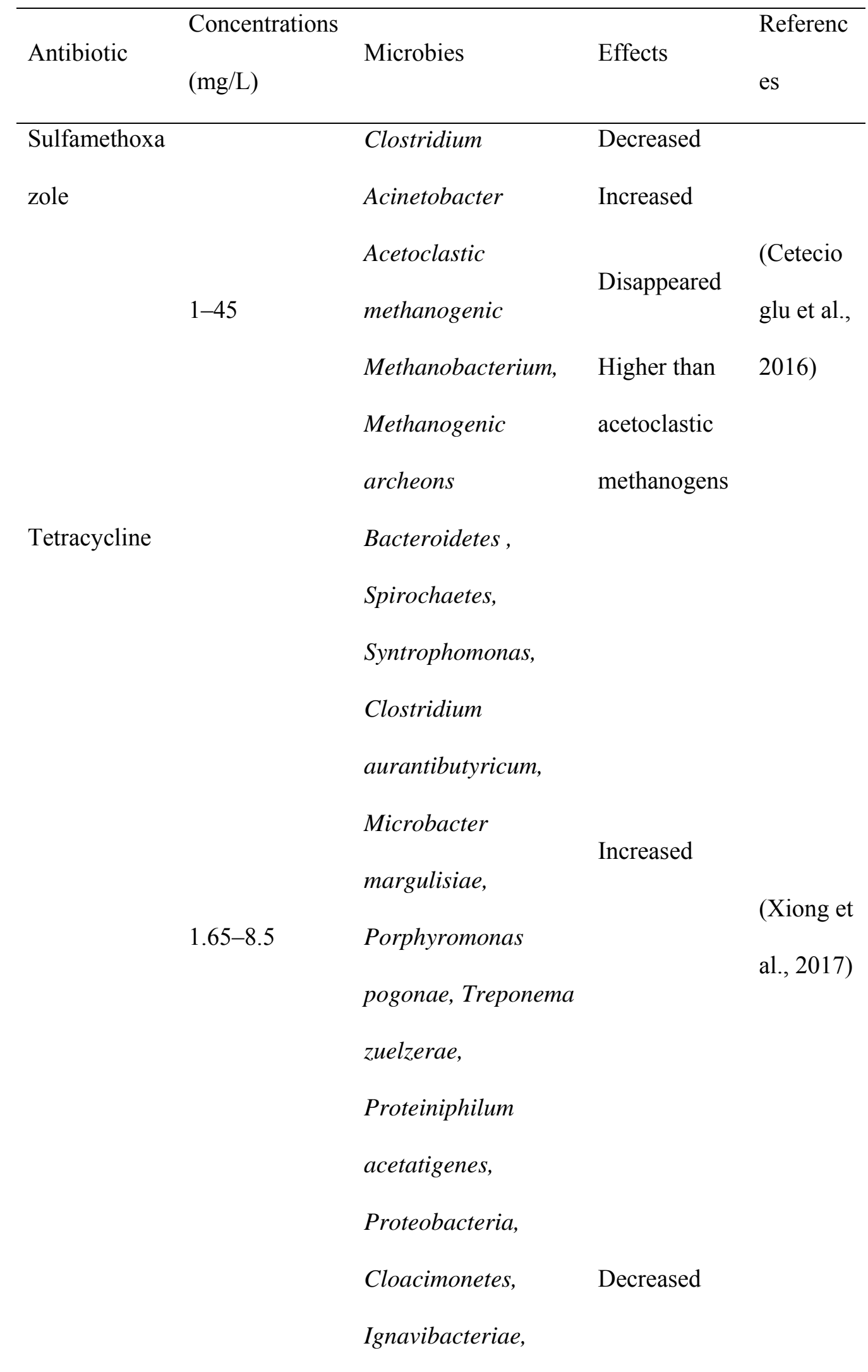




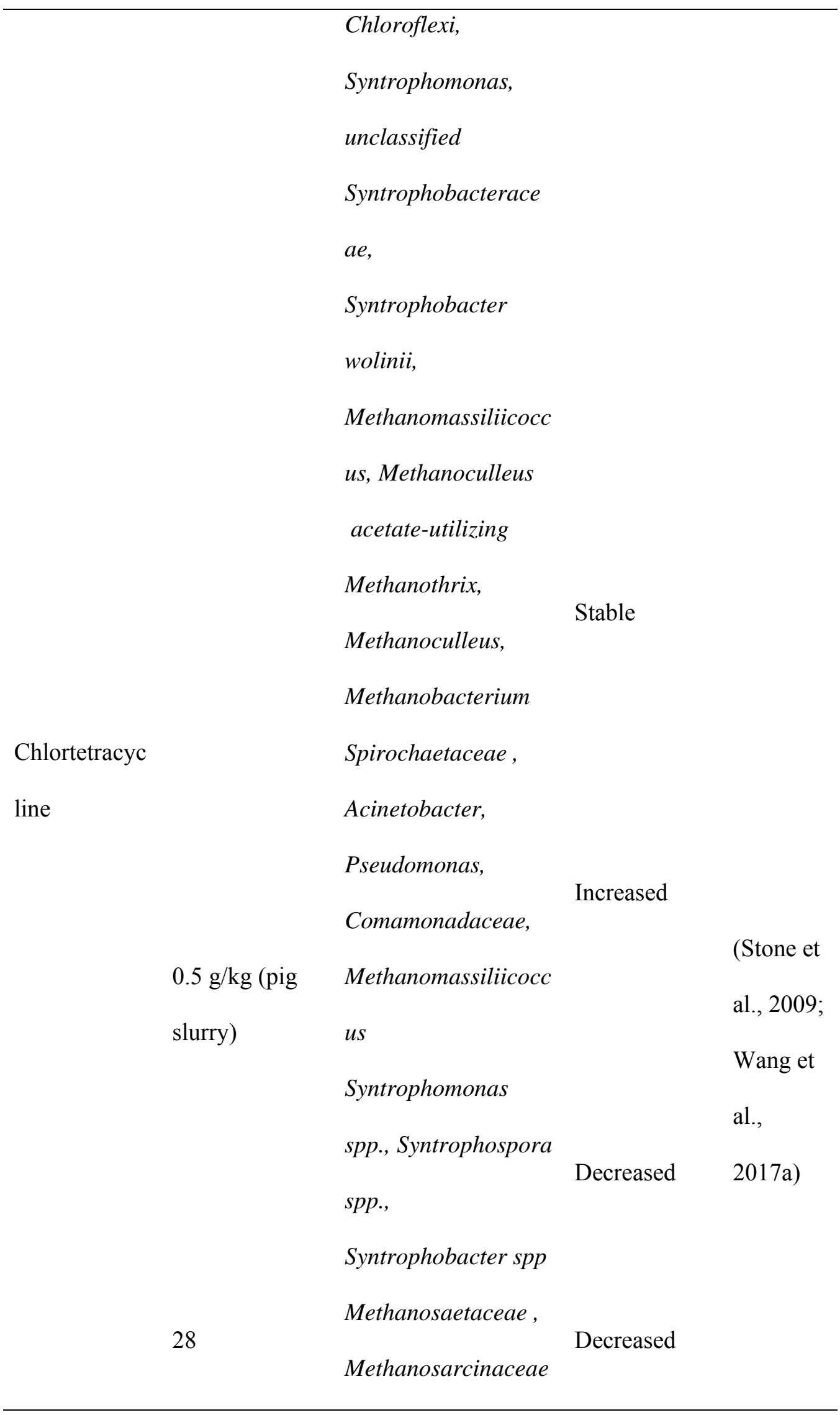




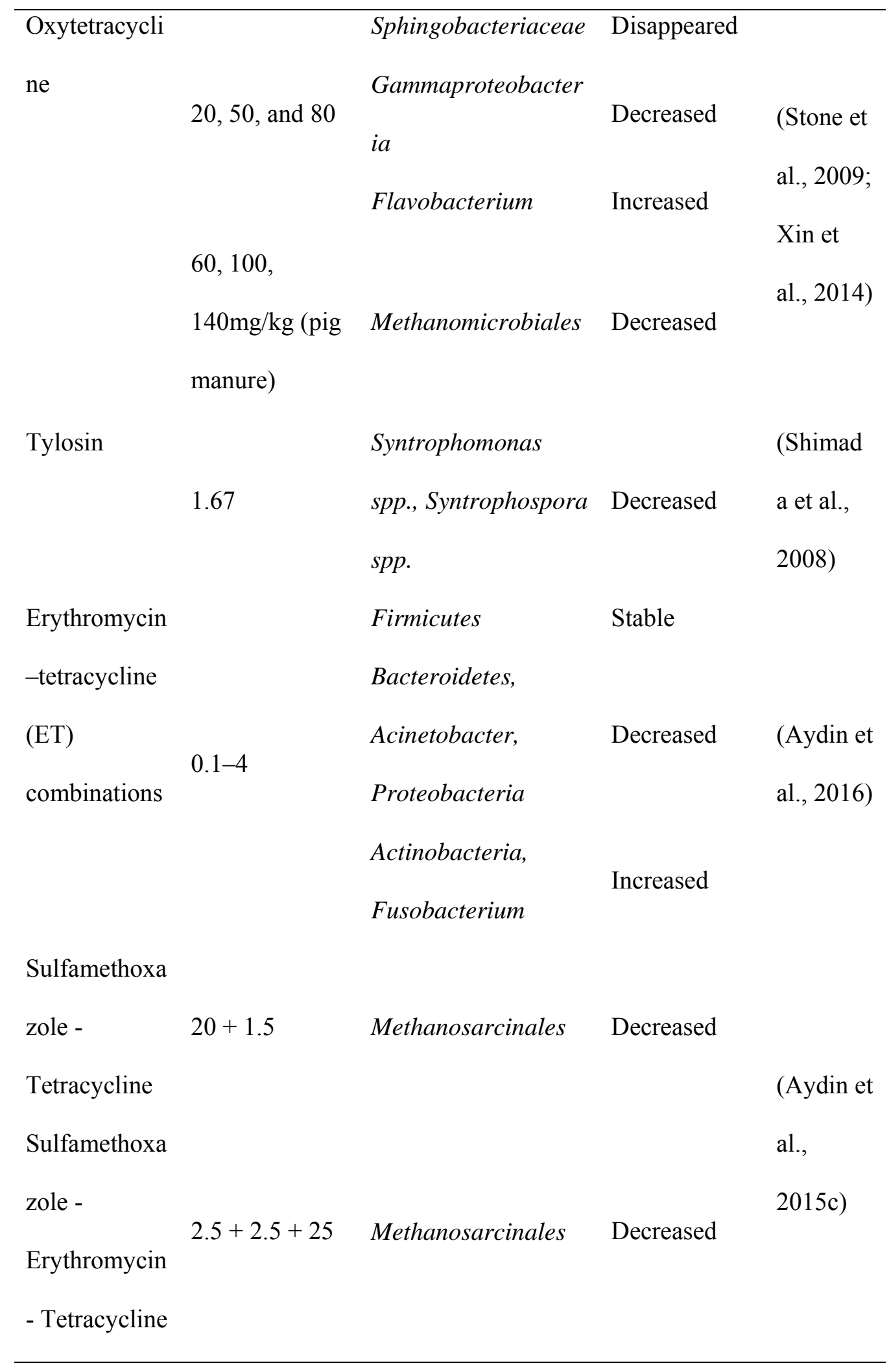

